Jurnal Ilmu Dan Teknologi Kesehatan

Vol 6, No 1, September 2018,

ISSN: 2338-9095 (Print)

ISSN: 2338-9109 (online)

\title{
Range Of Motion (ROM) Spherical Grip dapat Meningkatkan Kekuatan Otot Ekstremitas Atas Pasien Stroke
}

\author{
Gina Dwi Anggraini ${ }^{1}$, Septiyanti ${ }^{2}$, Dahrizal ${ }^{3}$ \\ Politeknik Kesehatan Kementerian Kesehatan Bengkulu \\ dahrizal26@ymail.com
}

\author{
Artikel history \\ Dikirim, Jun $20^{\text {th }}, 2018$ \\ Ditinjau, Aug $20^{\text {th }}, 2018$ \\ Diterima, Aug $27^{\text {th }}, 2018$
}

\section{ABSTRACT}

Stroke is lost brain function caused by stop his blood supply to the brain. As a result of the disruption of oxygen to the brain needs can occur the clinical manifestations included the weakness of some or all of the body limbs, one of over ekstremities so that the patient could not doing the activity because of the limbs weakness and they needs exercise for preveting disability. Objective is Know the effect of Range Of Motion (ROM) Spherical Grip on muscle strenght of upper extremity on stroke patients. The research used quasi-experimental with pretest and posttest with control group. The population in this study is all stroke patients in the neurological specialist RSUD dr. M. Yunus of Bengkulu City. The Sampling technique used is Cluster Sampling. The number of sample is 32. Instruments used for manual muscle testing. Test for normality using the Kolmogorov-Smirnov and analysis techniques using Wilcoxon Signed Ranks Test and Mann-Whitney with 95\% confidence level $(\alpha=0,05)$. Muscle strenght of the finger mean in the control group 2,44 increase to 2,63 with the difference 0,1875. In the intervention group mean 2,44 increase to 3,13 with the difference 0,6875. Muscle strenght of the wrist mean in the control group 2,38 increase to 2,56 with the difference 0,1875. In the intervention group mean 2,25 increase to 3,00 with the difference 0,75 . The result obtained p-value 0,011 finger hand and p-value 0,027 wrist. Exercise Range Of Motion (ROM) Spherical Grip is effective in increase muscle strenght of over extremities on stroke patients.

Key Word : Range Of Motion (ROM), Spherical Grip, Stroke, Muscle Strenght

\begin{abstract}
ABSTRAK
Stroke adalah kehilangan fungsi otak yang diakibatkan oleh berhentinya suplai darah ke bagian otak. Akibat dari terganggunya kebutuhan oksigen ke otak dapat terjadi manifestasi klinis berupa kelemahan sebagian atau seluruh anggota gerak dari tubuh, salah satunya ekstremitas atas sehingga pasien tidak mampu melakukan aktivitas karena kelemahan anggota gerak dan membutuhkan latihan anggota gerak yang bertujuan untuk mencegah kecacatan. Tujuan untuk mengetahui pengaruh range of motion (ROM) spherical grip terhadap kekuatan otot ekstremitas atas pada pasien post stroke. Desain dalam penelitian ini adalah quasi eksperimen dengan rancangan pretest and posttest with control group. Populasi dalam penelitian ini adalah seluruh pasien stroke di poli saraf RSUD Dr. M. Yunus
\end{abstract}


Bengkulu.. Teknik pengambilan sampel yang digunakan adalah Cluster sampling. Jumlah sampel penelitian ini 32 responden. Instrumen yang digunakan dalam pemeriksaan kekuatan otot menggunakan alat ukur manual muscle testing. Uji normalitas menggunakan Kolmogorov-Smirnov dan teknik analisis menggunakan Wilcoxon Signed Ranks Test dan Mann-Whitneyy dengan 95\% CI $(\alpha=0,05)$. Kekuatan otot jari tangan rata-rata pada kelompok kontrol 2,44 meningkat menjadi 2,63 dengan selisih 0,1875. Pada kelompok intervensi rata-rata 2,44 meningkat menjadi 3,13 dengan selisih 0,6875. Kekuatan otot pergelangan tangan rata-rata pada kelompok kontrol 2,38 meningkat menjadi 2,56 dengan selisih 0,1875. Pada kelompok intervensi rata-rata 2,25 meningkat menjadi 3,00 dengan selisih 0,75. Hasil diperoleh nilai p-value 0,11 jari tangan dan $p$-value 0,027 pergelangan tangan. Latihan Range Of Motion (ROM) Spherical Grip efektif meningkatkan kekuatan otot esktremitas atas pada pasien stroke.

Kata Kunci : Range Of Motion (ROM), Spherical Grip, Stroke, Kekuatan Otot.

\section{PENDAHULUAN}

Menurut UU Kesehatan No. 36 pasal 3 tahun 2009 pembangunan kesehatan bertujuan untuk meningkatkan kesadaran, kemauan, dan kemampuan hidup sehat bagi setiap orang agar terwujud derajat kesehatan masyarakat setinggi-tingginya, sebagai investasi bagi bangunan sumber daya manusia yang produktif secara sosial dan ekonomis, salah satu masalah yang dapat membatasi seseorang untuk hidup produktif adalah akibat menderita sakit (Suhardi, 2011).

Stroke terjadi akibat pembuluh darah yang membawa darah dan oksigen ke otak mengalami penyumbatan dan ruptur, kekurangan oksigen menyebabkan fungsi kontrol gerakan tubuh yang dikendalikan oleh otak tidak berfungsi (American Heart Association [AHA], 2015). Badan kesehatan dunia memprediksi bahwa kematian akibat stroke akan meningkat seiring dengan kematian akibat penyakit jantung dan kanker kurang lebih 6 juta pada tahun 2010 menjadi 8 juta di tahun 2030 (American Heart Association, 2010).

Stroke merupakan penyebab kecacatan nomor satu di dunia dan penyebab kematian nomor tiga di dunia setelah penyakit jantung dan kanker. Secara global, 15 juta orang terserang stroke setiap tahunnya, satu pertiga meninggal dan sisanya mengalami cacat permanen (Stroke forum, 2015). Berdasarkan American Heart Association (2013), pada tahun 2010, stroke menyebabkan kurang lebih 1 diantara 19 kematian di Amerika Serikat. Rerata setiap 40 detik, seseorang di Amerika Serikat terdiagnosis stroke, dan kira-kira satu orang meninggal dunia setiap 4 menit.

Prevalensi stroke di Indonesia pada tahun 2007 berdasarkan diagnosis tenaga kesehatan sebesar $6,0 \%$ dan yang berdasarkan diagnosis tenaga kesehatan atau gejala sebesar 8,3\% (Riskesdas,2007). 
Terjadi peningkatan prevalensi stroke di Indonesia pada tahun 2013 berdasarkan diagnosis tenaga kesehatan sebesar 7,0\% dan yang berdasarkan diagnosis tenaga kesehatan atau gejala sebesar 12,1\%. Prevalensi stroke terlihat meningkat seiring peningkatan umur responden dan sama banyak pada laki-laki dan perempuan.

Jumlah penderita penyakit stroke di Bengkulu tahun 2007 berdasarkan diagnosis tenaga kesehatan (Nakes) diperkirakan sebanyak 5,5\%, sedangkan berdasarkan diagnosis Nakes atau gejala diperkirakan sebanyak $6,5 \%$ (Riskesdas,2007). Pada tahun 2013 terjadi peningkatan berdasarkan diagnosis tenaga kesehatan (Nakes) diperkirakan 8,3\%, sedangkan berdasarkan diagnosis Nakes atau gejala diperkirakan 12,3\%. (Riskesdas, 2013). Berdasarkan survey di Poli Saraf RSUD Dr. M. Yunus Bengkulu, jumlah pasien stroke yang rawat jalan di Poli Saraf pada tahun 2014 berjumlah 1028, pada tahun 2015 berjumlah 811, dan pada tahun 2016 berjumlah 811 orang.

Kematian akibat stroke ditemukan pada $10-30 \%$ pasien yang dirawat dan $70-90 \%$ penderita yang hidup pasca stroke (Pinzon \& Asanti, 2010). Sekitar 90\% pasien stroke mengalami kecacatan atau kelumpuhan separuh badan. Kelumpuhan atau kelemahan ini seringkali masih dialami pasien sewaktu keluar dari rumah sakit (Mulyatsih \& Ahmad, 2008). Penderita stroke yang mengalami kelemahan otot dan tidak segera mendapatkan penanganan yang tepat dapat menimbulkan komplikasi, salah satunya adalah kontaktur yang menyebabkan terjadinya gangguan fungsional, gangguan mobilisasi, gangguan aktivitas sehari-hari dan cacat yang tidak dapat disembuhkan (Asmadi, 2008).

Stroke secara jelas dapat berdampak pada disfungsi ektremitas atas. Disfungsi ekstremitas atas ini merupakan gangguan fungsional yang paling umum terjadi pada penderita stroke, berupa kehilangan kontrol ekstremitas atas yang dapat menurunkan kekuatan otot. Ekstremitas atas merupakan salah satu bagian tubuh yang penting untuk dilakukan ROM dikarenakan ekstremitas atas fungsinya sangat penting dalam melakukan aktivitas sehari-hari dan merupakan bagian yang paling aktif. (Irfan, 2010).

Pasien stroke memerlukan rehabilitasi untuk meminimalkan cacat fisik, rehabilitas harus dimulai sedini mungkin secara cepat dan tepat sehingga dapat membantu pemulihan fisik yang lebih cepat dan optimal, serta menghindari kelemahan otot. Penderita stroke yang 
41 Jurnal Ilmu dan Teknologi Kesehatan, Vol 6 Nomor 1, September 2018, hlm : 38 - 48

mengalami kelemahan otot dan tidak segera mendapatkan penanganan yang tepat dapat menimbulkan komplikasi, salah satunya adalah kontaktur yang menyebabkan terjadinya gangguan fungsional, gangguan mobilisasi, gangguan aktivitas sehari-hari dan cacat yang tidak dapat disembuhkan (Asmadi, 2008).

Salah satu terapi gerak aktif yang dapat dilakukan dengan cara latihan menggenggam bola. Untuk membantu pemulihan bagian lengan atau bagian ekstremitas atas diperlukan teknik untuk merangsang tangan seperti dengan latihan spherical grip yang merupakan latihan fungsional tangan dengan cara menggenggam sebuah benda berbentuk bulat seperti bola pada telapak tangan (Prok,Gesal\&Angliadi,2016).

Latihan ROM aktif-asistif (spherical grip) merupakan latihan yang dapat menghasilkan peningkatan motor unit yang diproduksi asetilcholin, sehingga mengakibatkan kontraksi yang berdampak pada peningkatan kekuatan otot yang lebih baik (Irsyam, 2012).

Tujuan penelitian ini untuk mengetahui pengaruh range of motion (ROM) spherical grip terhadap kekuatan otot esktremitas atas pada pasien post stroke di Poli Saraf RSUD Dr. M. Yunus Bengkulu

\section{METODE}

Jenis penelitian ini merupakan penelitian analitik, dengan desain penelitian quasi eksperimental dengan pre-test and posttest with control group design. Penelitian dilakukan dari bulan Januari-Februari 2018. Populasi pada penelitian ini seluruh penderita stroke yang dirawat di Poli Saraf RSUD Dr. M.Yunus Bengkulu. Sampel pasien post stroke dengan usia kurang dari 65 tahun dengan hemiparesis ekstremitas atas sinistra/ dextra yang berjumlah 16 orang untuk masing-masing kelompok dengan menggunakan teknik cluster sampling. Pengumpulan data menggunakan Manual Muscle Testing (MMT). Selanjutnya data yang diperoleh ditulis pada lembar observasi.

Analisa data yang digunakan yaitu analisa univariat dan disajikan dalam bentuk tabel dan analisis secara deskriptif. Analisa bivariat menggunakan uji Wilcoxon Signed Ranks Test dan uji Mann-Whitney dengan 95\% confidence level untuk melihat pengaruh latihan Range Of Motion (ROM) spherical grip terhadap kekuatan otot ekstremitas atas.

\section{HASIL DAN PEMBAHASAN}

1. Analisis Univariat

Pada tabel 1 didapatkan hasil rerata usia pasien post stroke yaitu 53,81 tahun pada kelompok intervensi dan 59,50 tahun pada kelompok kontrol. Jenis kelamin sebagian 
besar laki-laki $62,5 \%$ pada kelompok intervensi dan sebagian pada kelompok kontrol laki-laki 50\%. Tingkat pendidikan pada kelompok intervensi sebagian adalah perguruan tinggi 50\% dan pada kelompok kontrol sebagian kecil adalah perguruan tinggi $37 \%$. Jenis stroke sebagian besar stroke iskemik $62,5 \%$ pada kelompok intervensi dan kelompok kontrol 93,8\% stroke iskemik. Dan frekuensi stroke sebagian besar serangan pertama $81,3 \%$ pada kelompok intervensi dan kelompok kontrol $75 \%$ serangan pertama.

Tabel 1 karakteristik responden pada pasien post stroke

\begin{tabular}{lcc}
\hline \multicolumn{1}{c}{ Karakteristik } & Intervensi & Kontrol \\
\hline Usia & & \\
Mean & 53,81 & 59,50 \\
Median & 53,00 & 60,00 \\
SD & 6,814 & 4,147 \\
Min-Maks & $41-64$ & $51-64$ \\
\hline Jenis Kelamin & & \\
Laki-laki & $10(62,5 \%)$ & $8(50,0 \%)$ \\
Perempuan & $6(37,5 \%)$ & $8(50,0 \%)$ \\
\hline Pendidikan & & \\
SD & $0(0 \%)$ & $2(12,5 \%)$ \\
SMP & $3(18,8 \%)$ & $4(25,0 \%)$ \\
SMA & $5(31,3 \%)$ & $4(25,0 \%)$ \\
PT & $8(50,0 \%)$ & $6(37,5 \%)$ \\
\hline Jenis Stroke & & \\
Hemoragik & $6(37,5 \%)$ & $1(6,3 \%)$ \\
Iskemik & $10(62,5 \%)$ & $15(93,8 \%)$ \\
\hline Frekuensi Stroke & $3(18,8 \%)$ & $4(25,0 \%)$ \\
Serangan kedua/ lebih & $13(81,3 \%)$ & $12(75,0 \%)$ \\
Serangan pertama & &
\end{tabular}

Tabel 2 menunjukkan bahwa rerata kekuatan otot jari tangan sebelum diberikan perlakuan pada kelompok intervensi 2,44 dengan standar deviasi 0,629 dengan nilai kekuatan otot terendah 1 dan tertinggi 3 , sesudah diberikan perlakuan didapatkan rerata kekuatan otot 3,13 dengan standar deviasi 0,500 dengan nilai kekuatan otot terendah 2 dan tertinggi
4. Sedangkan rerata kekuatan otot jari tangan sebelum diberikan perlakuan pada kelompok kontrol 2,44 dengan standar deviasi 0,512 dengan nilai kekuatan otot terendah 2 dan nilai tertinggi 3, sesudah diberikan perlakuan didapatkan rerata 2,63 dengan standar deviasi 0,500 dengan nilai kekuatan otot terendah 2 dan tertinggi 3. 
Tabel 2 Distribusi Rerata Kekuatan Otot Ekstremita Atas Jari Tangan Pada Pasien Post Stroke $(n=32)$

\begin{tabular}{ccccc}
\hline \multirow{2}{*}{ Kekuatan Otot } & \multicolumn{4}{c}{ Kelompok } \\
\cline { 2 - 5 } Intervensi & \multicolumn{2}{c}{ Kontrol } \\
\hline & Sebelum & Sesudah & Sebelum & Sesudah \\
\hline Mean & 2,44 & 3,13 & 2,44 & 2,63 \\
\hline Median & 2,50 & 3,00 & 2,00 & 3,00 \\
\hline SD & 0,629 & 0,500 & 0,512 & 0,500 \\
\hline Min-Maks & $1-3$ & $2-4$ & $2-3$ & $2-3$ \\
\hline
\end{tabular}

Tabel 3 menunjukkan bahwa rerata kekuatan otot pergelangan tangan sebelum diberikan perlakuan pada kelompok intervensi 2,25 dengan standar deviasi 0,577 dengan nilai kekuatan otot terendah 1 dan tertinggi 3 , sesudah diberikan perlakuan didapatkan rerata kekuatan otot 3,00 dengan standar deviasi 0,516 dengan nilai kekuatan otot terendah 2 dan tertinggi
4. Sedangkan rerata kekuatan otot pergelangan tangan sebelum diberikan perlakuan pada kelompok kontrol 2,38 dengan standar deviasi 0,500 dengan nilai kekuatan otot terendah 2 dan nilai tertinggi 3, sesudah diberikan perlakuan didapatkan rerata 2,56 dengan standar deviasi 0,512 dengan nilai kekuatan otot terendah 2 dan tertinggi 3.

Tabel 3 Distribusi Rerata Kekuatan Otot Ekstremita Atas Pergelangan Tangan Pada Pasien Post Stroke $(n=32)$

\begin{tabular}{ccccc}
\hline \multirow{2}{*}{ Kekuatan Otot } & \multicolumn{4}{c}{ Kelompok } \\
\cline { 2 - 5 } & \multicolumn{2}{c}{ Intervensi } & \multicolumn{2}{c}{ Kontrol } \\
\hline & Sebelum & Sesudah & Sebelum & Sesudah \\
\hline Mean & 2,25 & 3,00 & 2,28 & 2,56 \\
\hline Median & 2,00 & 3,00 & 2,00 & 3,00 \\
\hline SD & 0,577 & 0,516 & 0,500 & 0,512 \\
\hline Min-Maks & $1-3$ & $2-4$ & $2-3$ & $2-3$ \\
\hline
\end{tabular}

2. Analisis Bivariat

Tabel 4 Pengaruh Latihan Range Of Motion (ROM) Spherical Grip Terhadap Kekuatan Otot Ekstremitas Atas Jari Tangan

\begin{tabular}{lcccc}
\hline \multicolumn{1}{c}{ Kekuatan otot } & $\mathbf{n}$ & Mean rank & Sum of rank & $\boldsymbol{p}$-value \\
\hline Kelompok Intervensi & 16 & 6,00 & 66,00 & 0,001 \\
\hline Kelompok Kontrol & 16 & 2,00 & 6,00 & 0,083 \\
\hline
\end{tabular}

Berdasarkan tabel 4 pada kelompok intervensi bahwa ada pengaruh latihan range of motion ( $\mathrm{ROM}$ ) spherical grip terhadap kekuatan otot esktremitas atas 
jari tangan pada pasien post stroke di Poli Saraf RSUD Dr. M. Yunus Bengkulu. Sedangkan pada kelompok kontrol tidak ada pengaruh range of motion (ROM)

Tabel 5 Pengaruh Latihan Range Of Motion (ROM) Spherical Grip

Terhadap Kekuatan Otot Ekstremitas Atas PergelanganTangan

\begin{tabular}{lcccc}
\hline \multicolumn{1}{c}{ Kekuatan otot } & $\mathbf{N}$ & Mean rank & Sum of rank & $\boldsymbol{p}$-value \\
\hline Kelompok Intervensi & 16 & 6,50 & 78,00 & 0,001 \\
\hline Kelompok Kontrol & 16 & 2,00 & 6,00 & 0,083 \\
\hline
\end{tabular}

Berdasarkan tabel 5 pada kelompok intervensi bahwa ada pengaruh latihan range of motion (ROM) spherical grip terhadap kekuatan otot esktremitas atas pergelangan tangan pada pasien post stroke di Poli Saraf RSUD Dr. M. Yunus pasif terhadap kekuatan otot ekstremitas atas jari tangan pada pasien post stroke di Poli Saraf RSUD Dr. M. Yunus Bengkulu.

Tabel 6 Perbedaan Kekuatan Otot Ekstremitas Atas Jari Tangan pasien stroke

\begin{tabular}{cccc}
\hline \multirow{2}{*}{$\begin{array}{c}\text { Kelompok } \\
(\mathbf{n}=32)\end{array}$} & $\mathbf{Z}$ & Mean Rank & p-value \\
\cline { 3 - 4 } & & \multicolumn{3}{c}{ Kekuatan Otot } \\
\cline { 1 - 1 } Kelompok Intervensi & $-2,543$ & 19,94 & 0,011 \\
\cline { 1 - 1 } & & 13,06 & \\
\hline
\end{tabular}

Berdasarkan tabel 6 bahwa ada perbedaan kekuatan otot ekstremitas atas pada
Bengkulu. Sedangkan pada kelompok kontrol tidak ada pengaruh range of motion (ROM) pasif terhadap kekuatan otot ekstremitas atas pergelangan tangan pada pasien post stroke di Poli Saraf RSUD Dr. M. Yunus Bengkulu.

Tabel 7 Perbedaan Kekuatan Otot Ekstremitas Atas Pergelangan Tangan pasien stroke

\begin{tabular}{cccc}
\hline $\begin{array}{c}\text { Kelompok } \\
(\mathbf{n = 3 2})\end{array}$ & $\mathbf{Z}$ & Mean Rank & p-value \\
\cline { 3 - 3 } & \multirow{2}{*}{$\begin{array}{c}\text { Kekuatan Otot } \\
\text { Kelompok Intervensi }\end{array}$} & $-2,214$ & 19,56 \\
\hline Kelompok Kontrol & & 13,44 & \\
\hline
\end{tabular}

Berdasarkan tabel 7 bahwa ada perbedaan kekuatan otot ekstremitas atas pada kelompok intervensi dengan kelompok kontrol. 
45 Jurnal IImu dan Teknologi Kesehatan, Vol 6 Nomor 1, September 2018, hlm : 38 - 48

\section{Pembahasan}

Hasil penelitian menjukkan bahwa ada pengaruh setelah diberikan latihan Range of Motion (ROM) Spherical Grip sebanyak 2 kali sehari dalam waktu 10 menit selama 7 hari berutut-turut sehingga terjadi peningkatan skala kekuatan otot. Range Of Motion (ROM) Spherical Grip merupakan latihan untuk menstimulasi gerak pada tangan yang berupa latihan fungsi menggenggam yang dilakukan melalui 3 tahap yaitu membuka tangan, menutup jari-jari untuk menggenggam objek dan mengatur kekuatan menggenggam sebuah benda berbentuk bulat seperti bola pada telapak tangan (Irfan, 2010). Pada saat latihan Range of Motion (ROM) Spherical Grip ada penyebaran mencengkram yang lebih besar dijari, tulang sendi metacarphopalangeal menghasilkan tarikan lebih banyak daripada aktifitas interoseus (Kaplan, 2005).

Didukung dalam penelitian Olviani (2017) menyatakan spherical grip merupakan latihan fungsional tangan dimana saat responden melakukan latihan dengan bola, beban yang diangkat lebih besar daripada responden yang melakukan latihan dengan benda lain yang menyebabkan kontraksi otot dengan tenaga yang besar dan kontraksi yang terjadi lebih kuat sehingga menghasilkan peningkatan motor unit yang diproduksi asetilcolin, sehingga mengakibatkan kontraksi. Mekanisme yang dilakukan melalui latihan ini berdampak pada peningkatan kekuatan otot yang lebih baik (Irsyam, 2012).

Langkah-langkah latihan Range of Motion (ROM) Spherical Grip dilakukan dengan memberikan bola, kemudian lakukan koreksi pada jari-jari responden agar menggenggam sempurna, lalu posisikan wrist joint (pergelangan tangan) 45 derajat, selanjutnya berikan instruksi kepada responden untuk menggenggam (menggenggam kuat) selama 5 detik kemudian rileks. Lakukan pengulangan sebanyak 7 kali. (Irfan, 2010). Latihan ini mengakibatkan kontraksi yang berdampak pada peningkatan kekuatan otot yang lebih baik.

Keberhasilan penerapan Range of Motion (ROM) Spherical Grip memberikan dampak positif terhadap peningkatan kekuatan otot ekstremitas atas pada pasien post stroke. Hal ini berimplikasi bahwa latihan Range of Motion (ROM) Spherical Grip dapat dijadikan sebagai alternatif terapi latihan dalam proses rehabilitasi pasien post stroke yang dapat digunakan oleh perawat untuk upaya pencegahan terjadinya kondisi cacat permanen pada pasien paska perawatan dirumah sakit. Didukung dengan penelitian yang dilakukan oleh Olviani dkk (2017) yang 
menyebutkan latihan Range of Motion (ROM) Spherical Grip merupakan salah satu bentuk intervensi fundamental perawat yang dapat meningkatkan kekuatan otot ekstremits atas pada pasien post stroke.

\section{SIMPULAN}

Berdasarkan hasil penelitian dan pembahasan ada peningkatan kekuatan otot ekstremitas atas jari dan pergelangan tangan pada pasien post stroke setelah diberikan latihan range of motion (ROM) spherical grip, sehingga intervensi ini dapat dijadikan sebagai salah satu intervensi yang tepat pada pasien post stroke.

Hasil penelitian ini diharapkan dapat memberikan tambahan informasi kepada masyarakat dalam penanganan pasien post stroke yang mengalami hemiparesis. Selain itu, penelitian ini juga dapat memberikan masukan kepada instansi terkait Poli Saraf RSUD Dr. M. Yunus Bengkulu dalam memberikan penyuluhan kesehatan terkait latihan yang dapat meningkatkan kekuatan otot, sebagai salah satu upaya mengurangi kecacatan dan meningkatkan fungsi kemandirian pasien sehingga pasien dapat melakukan aktivitas sehari-hari. Peneliti selanjutnya diharapkan dapat mengembangkan penelitian dengan meneliti teknik latihan lain sehingga dapat memperkaya hasil penelitian pada jenis latihan untuk peningkatan kekuatan otot ektremitas atas.

\section{DAFTAR PUSTAKA}

American Heart Association. (2010). Heart diseases and stroke statistic: Our guide to curret statistics and the supplement to our heart and stroke fact-2010 update. Diperoleh dari http://www.americanheart.org.

Diakses pada tangggal 20 September 2017

American Heart Association. (2013) Guidelines for the Early Management of Patient With Acute Ischemic Stroke A Guideline for Healthcare Professionals. Diperoleh dari http://stroke.ahajournals.org. Diakses pada tangggal 20 September 2017

Asmadi. (2008). Konsep dan Aplikasi Kebutuhan Dasar Klien. Jakarta : Salemba Medika

Brunner dan suddarth. (2002). Buku Ajar Keperawatan Medikal Bedah. Edisi 8 volume 2. EGC. Jakarta

Corwin, J.E. (2001). Buku Saku Patofisiologi. EGC. Jakarta.

Dewanto, G, Suwono, wita J, riyanto, Budi, Turana, Yuda, (2009). Panduan Praktis Diagnosis \& Tata Laksana Penyakit Saraf. EGC. Jakarta.

Doenges, Marilynn E, Mary Frances Moohause dan Alice C. Geisser. (2000) Rencana Asuhan Keperawatan : Pedoman Untuk Perencanaan dan Pendokumentasian Perawatan Pasien. EGC. Jakarta. 
Fatkhurrohman, Muhammad. (2011). Pengaruh Latihan Motor Imagery Terhadap Kekuatan Otot Ekstremitas Pada Pasien Stroke Dengan Hemiparesis Di Rumah Sakit Umum Daerah Kota Bekasi. Universitas Indonesia.

Goldszmidt, (2002). Esensial Stroke. Penerbit Buku Kedokteran EGC : Jakarta

Irfan, Muhammad.(2010). Fisioterapi Bagi Insan Stroke. Graha Ilmu. Yogyakarta.

Junaidi, Iskandar.(2011). Stroke Waspadai Ancamannya. ANDI. Yogyakarta.

Kemenkes RI. (2014). Parvelensi Hipertensi, Penyakit Membahayakan. Jakarta

Ling Yang, et al. (2012). Pilot Comparative Study of Unilateral Dan Bilateral Robot-Assisted Training On Upper-Extremity Performance In Patients With Stroke. National Taipei University.

Lumbantobing, S. M (2008). Neurologi klinik : Pemeriksaan fisik dan mental Cetakan ke- 11. Balai Penerbit FKUI, Jakarta.

Mansjoer, A. (2000). Kapita Selekta Kedokteran Edisi 3 Jilid I. Media Aesculapis FKUI, Jakarta.

Mardati et al. (2014). Perbedaan Range Of Motion Spherical Grip Dan Cylindrical Grip Terhadap Kekuatan Otot Ekstremitas Atas Pada Pasien Stroke Di RSUD Tugurejo Semarang. Stikes Telogorejo Semarang.

Misbach, J. (2007). Stroke, Aspek Dignostik, Patofisiologi, Manjemen,
Edisi pertama, BP FK Universitas Indonesia, Jakarta

Nursalam. (2008). Konsep dan penerapan metodologi penelitian ilmu keperawatan. Edisi 2. Salemba Medika. Jakarta.

Notoatmojo, S. (2005). Metodologi Penelitian Kesehatan. Rineka Cipta. Jakarta.

Oliviani, et al. (2017). Pengaruh Latihan Range Of Motion (ROM) AktifAsistif (Spherical Grip) Terhadap Peningkatan Kekuatan Otot Ekstremitas Atas Pada Pasien Stoke Di Ruang Rawat Inap Penyakit Saraf (Seruni) RSUD Ulin Banjarmasin. Universitas Muhammadiyah Banjarmasin

Pinzon, R., \& Asanti, L. (2010). Awas stroke! (pengertian, gejala, tindakan, perawatan, dan pencegahan). Andi Offset. Yogyakarta

Potter \& Perry. (2005). Buku Ajar Fundamental Keperawatan Konsep, Proses, dan Praktik. Edisi 4 Volume 1. EGC. Jakarta

RISKESDAS.(2007). Laporan Hasil Riset Kesehatan Dasar (Riskesdas) 2007. Jakarta.https://www.k4health.org/sit es/default/files/laporanNasional\%20 Riskesdas\%202007.pdf. Diakses pada tangggal 10 Oktober 2017

RISKESDAS.(2013).Laporan Hasil Riset Kesehatan Dasar (Riskesdas) 2013. Jakarta.http://www.depkes.go.id/res ources/download/general/Hasil\%20 Riskesdas\%202013 . Diakses pada tangggal 26 September 2017

Sutrisno, A, (2007). Stroke Sebaiknya Anda Tahu Sebelum Anda Terserang 
Stroke. PT. Gramedia Pustaka Utama, Jakarta
Smeltzer S.C \& Bare (2002). Buku Ajar Keperawatan Medikal Bedah Brunner \& Suddart. Edisi 8 Volume 3. EGC. Jakarta. 